\title{
Cryptic speciation in the Recent thecideide brachiopod Thecidellina in the Atlantic and the Caribbean
}

\author{
Carsten Lüter ${ }^{1}$, Jana Hoffmann ${ }^{1}$ and Alan Logan ${ }^{2}$ \\ ${ }^{1}$ Museum für Naturkunde der Humboldt-Universität zu Berlin, Invalidenstraße 43, 10115 Berlin, Germany \\ E-mail: carsten.lueter@museum.hu-berlin.de \\ ${ }^{2}$ Department of Physical Sciences, University of New Brunswick, Saint John, New Brunswick E2L 4L5, Canada
}

\begin{abstract}
Ultrastructural examination of the brachiopod Thecidellina from three different locations in the Caribbean and the Atlantic revealed that at least three cryptic species are present. One is the type species of the genus, Thecidellina barretti, which may only occur in Jamaica. The other two, previously lumped into T. barretti, are new to science, viz T. bahamiensis Lüter \& Logan sp. nov. from the Bahamas and T. williamsi Lüter \& Logan sp. nov. from Cape Verde. All three species clearly differ not only in their provenance, but also in specific shell characters, such as spiculation of the ventral valve, presence of a ventral median ridge, shape of two holes in the intrabrachial ridge of the dorsal valve and the structure of the interbrachial lobes. The identification of three instead of a single species and their supposed allopatric speciation is discussed with regard to the thecideide life cycle and independent models of larval dispersal in the Caribbean, based on oceanographic data.
\end{abstract}

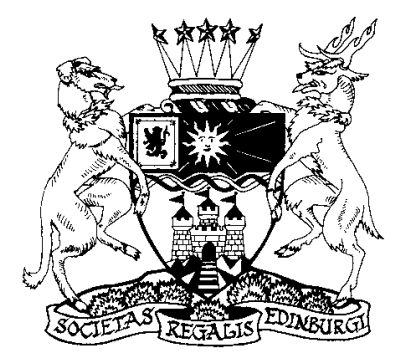

KEY WORDS: Brachiopoda, Jamaica, Bahamas, Cape Verde

Recent thecideide brachiopods comprise two subfamilies, Thecidellininae and Lacazellinae, with the recently described genus Kakanuiella having an uncertain affiliation (see Lüter 2005). Whereas the Lacazellinae so far comprises three genera (Lacazella, Pajaudina and Ospreyella), the Thecidellininae has only one Recent genus, Thecidellina. Six species of Thecidellina have been described so far from localities as far apart as the Caribbean, the north and south Indian Ocean, and the midPacific. Of particular interest are those Thecidellina specimens which have been identified as conspecific, although their localities are separated by thousands of kilometres of open sea. Why is this? All thecideide brachiopods protect their offspring in brood pouches and despite fundamental differences in the morphology of the structures involved in brood protection (Lacaze-Duthiers 1861; Logan 2004, 2005; Lüter 2005, 2007), the elaborate method of rearing larvae in a rather enclosed part of the mantle is similar in both subfamilies. It has been proposed that the larval dispersal ability of articulated brachiopods with brood protection is rather low (James et al. 1992; Richardson 1997). This is especially true for thecideides, not only because their lecithotrophic developmental stages are kept in the parental brood pouches until their larvae escape for metamorphosis, but the adults also dwell in cryptic habitats (on undersides of corals, in crevices and caves) so that larvae escaping from the brood pouch have almost no chance of reaching strong currents in order to travel long distances. Additionally, as lecithotrophic larvae with no ability to feed, thecideide developmental stages have to metamorphose as soon as possible after release from the parental brood pouch and normally survive only hours to days in the plankton. Lecithotrophic larvae of the Antarctic terebratulid Liothyrella uva can survive 80 to 100 days in the plankton (Meidlinger et al. 1998; Peck et al. 2001), thereby having the potential to travel up to several thousand kilometres along the coasts of the
Antarctic continent. However, in contrast to $L$. uva, which lives in extremely cold waters forcing the metabolic rates of the larvae to low levels, the low latitude distribution of Thecidellina species does not allow for retardation of development and metabolism due to the relatively high water temperatures surrounding their swimming larvae.

In this paper we investigate the peculiar case of the distribution of the Atlantic thecideide species Thecidellina barretti, the type species of Thecidellina, originally described by Davidson (1864) as Thecidium barretti from the north-east coast of Jamaica, Caribbean. Over the last few decades, specimens of Atlantic Thecidellina have been collected from other locations, such as the Bahamas (Cooper 1977) and Cape Verde (Logan 1988). Due to seemingly morphological similarity with $T$. barretti, all these specimens have been attributed to this Caribbean species despite the maximum distance between the Bahamian and Cape Verdean collecting localities of about $5500 \mathrm{~km}$. With genetic studies still to come, the present authors, as a first attempt, here re-examine by scanning electron microscopy (SEM) the skeletal structure of several Atlantic Thecidellina specimens from all three localities, resulting in a clear morphological differentiation of Caribbean, Bahamian and Cape Verdean Thecidellina. As a consequence, the specimens from Cape Verde and those from the Bahamas are described as new species, Thecidellina williamsi Lüter \& Logan sp. nov. and Thecidellina bahamiensis Lüter \& Logan sp. nov., respectively.

\section{Materials and methods}

The Thecidellina specimens available in this study come from different collections accumulated by the first and the third authors over the last three decades (for details see Fig. 1 and 


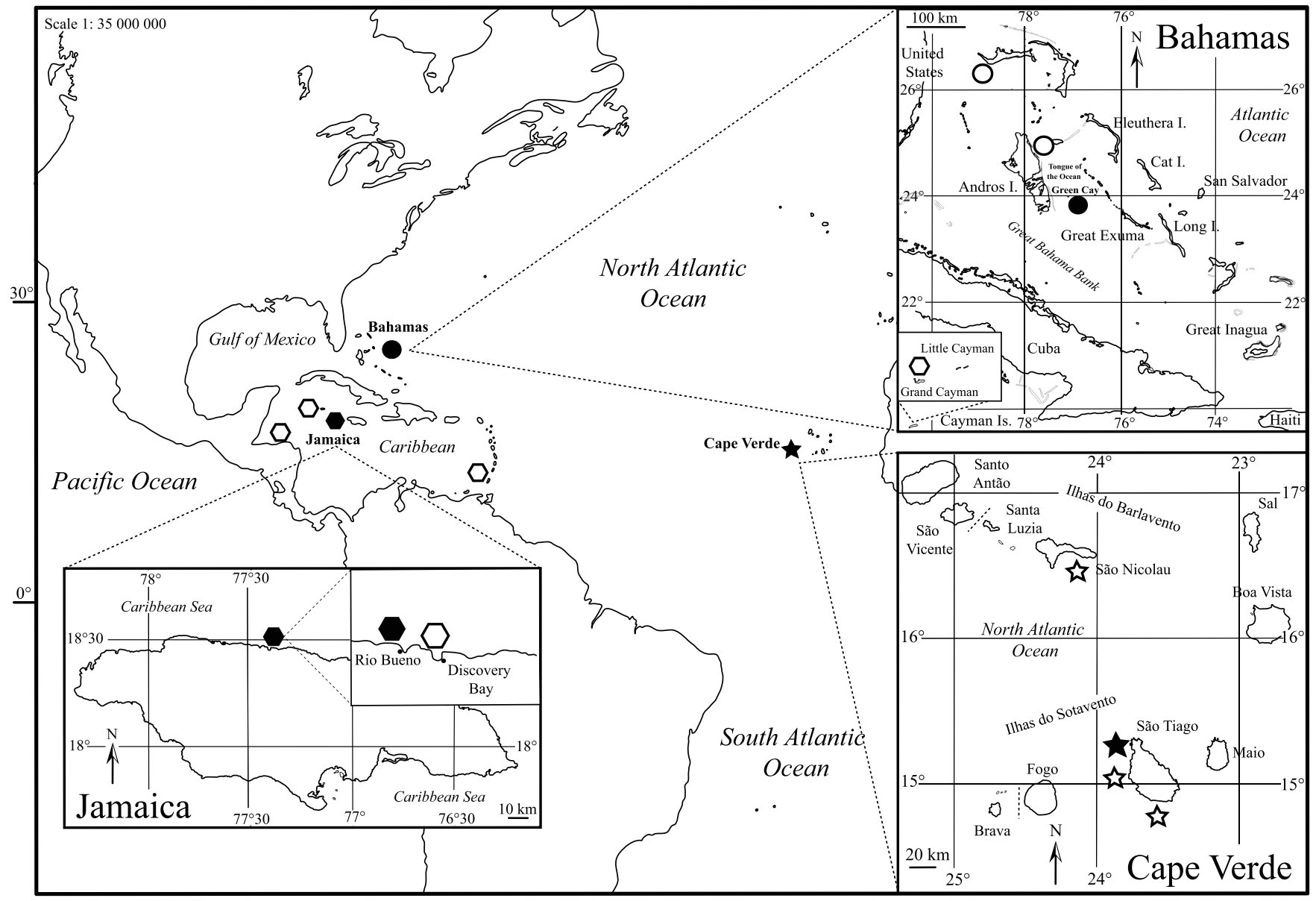

Figure 1 Map of collecting sites, where specimens of Thecidellina examined in the present study have been found. Inserts show details of the three type localities, Jamaica, Bahamas and Cape Verde with the three symbols (hexagon, circle and star) representing T. barretti, T. bahamiensis sp. nov. and T. williamsi sp. nov., respectively. Open symbols represent unfigured material.

Table 1). Most specimens were collected live and initially fixed in $80-90 \%$ ethanol. To expose the delicate inner shell structures for SEM investigation, specimens were treated either with $50 \%$ diluted household bleach or 3\% sodium hypochlorite to remove the soft tissue. After rinsing with water the dried dorsal and ventral valves were mounted on aluminium stubs, sputter coated with palladium-gold and examined in LEO VP 1450 (Berlin) and JEOL 6400 (Saint John) scanning electron microscopes. Digital photographs of the specimens were arranged in panels using ADOBE Photoshop 6.0 and ADOBE Illustrator 10 software.

\section{Results}

\subsection{General morphology, overall shape and common characteristics}

All three species are rather similar in terms of shell outline, size, depth range and geographical distribution (Table 1). The ventral valve is cemented to the substrate with variable orientation of the cicatrix (attachment scar) from parallel to perpendicular to the commissural plane, probably depending on the orientation of the underlying substrate. The ventral valve umbo is dorsally covered by a triangular, flat interarea (e.g. Fig. 2g, h) with no sign of a pseudodeltidium. The interarea is sometimes slightly curved (Fig. 2d), but, like the position of the cicatrix, this is highly variable within all three species. The dorsal valve is interlocked with the ventral valve by rather sturdy (ventral) teeth (Fig. 3c, f, i) and the corresponding (dorsal) sockets. Additionally, a squarish and relatively large cardinal process equipped with a pair of diductor muscles connects both valves and serves as a lever arm for shell opening. One pair of adductor muscles serves to close the shell with one muscle strand attached on either side of the cardinal process in the dorsal valve (Fig. $3 \mathrm{~m}$ ) and ventrolaterally of either tooth in the ventral valve (Fig. 3c, f, i), thereby leaving characteristic imprints (adductor muscle scars) in the calcitic shell. The shape and size of the adductor muscle scars vary within the species and cannot be used for species discrimination. The adductor muscle scars are somewhat kidney-shaped with the dorsal end often slightly pointed giving the scar an 'inverted drop'-like appearance. Both valves in all three species consist exclusively of primary layer shell material (Williams 1973) with the exception of the lateral parts of the cardinal process, the inner socket ridges (Fig. 3m), edges of the teeth (Fig. 3c, f, i), and the tubercles, on top of which are small areas of fibrous secondary shell layer (Fig. 3k, 1). All shells are densely punctate. When it comes to the inner architecture of both dorsal and ventral valves, however, species-specific morphological differences become obvious. They are described in detail in the following section, with the specimens from the type locality Jamaica clearly identified as $T$. barretti (Davidson, 1864), perfectly in line with the original description and subsequent listings and illustrations. In contrast, the other two sets of specimens from the Bahamas and Cape Verde show enough specific morphological characters to justify their status as two new species, the original descriptions of which are given below. 
THECIDELLINA BARRETTI SPECIES COMPLEX

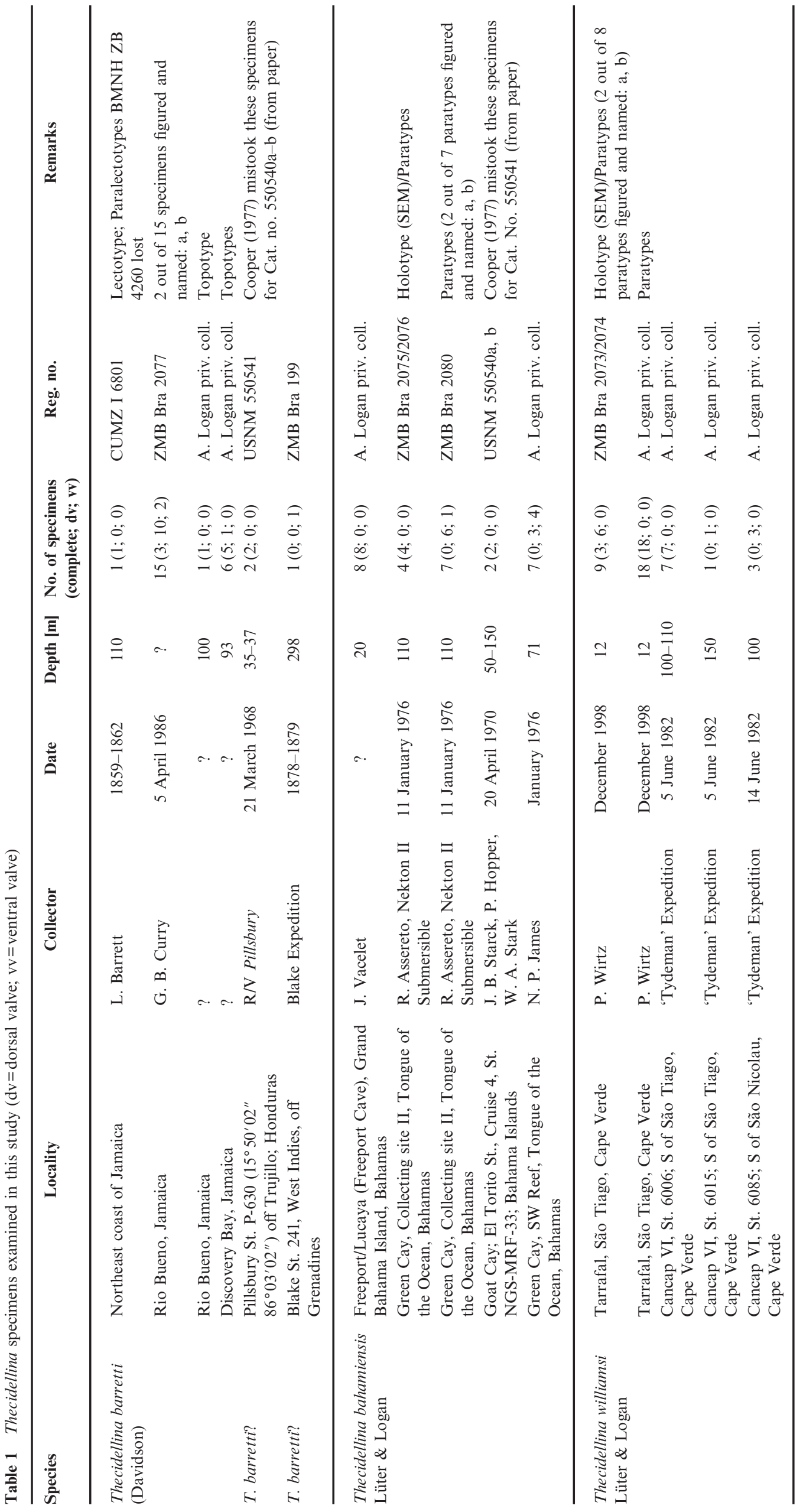




\subsection{Taxonomic description}

\section{Thecidellina barretti (Davidson)}

Figures $2 \mathrm{a}-\mathrm{c}, 3 \mathrm{a}-\mathrm{c}$

Thecidium barretti Davidson, 1864, p. 17, pl. II, figs. 1-3 (original description)

-as Thecidellina barretti: Thomson, 1915, p. 462 (new combination)

Type specimens. CUMZ I 6801, lectotype (1, valves separated), dry (subsequent designation). A second set of syntypes (now paralectotypes) was originally part of the Davidson collection, preserved at the NHM, London under the accession number BMNH ZB 4260. These specimens could neither be found by Lee \& Robinson (2003) nor by the first author, hence the lectotype designation of the Cambridge type material.

Type locality. Collected 'by the late Lucas Barrett at 60 fathoms on the north east coast of Jamaica' (Davidson 1864, p. 18).

Additional material. Topotypes are available from the fore-reef slope at about $100 \mathrm{~m}$ depth from Rio Bueno and from Discovery Bay, Jamaica (see Table 1). The affiliation of specimens determined as $T$. barretti from Honduras (Cooper 1977), Grand Cayman (Logan 1977, 1981) and off the Grenadines (ZMB Bra 199) remains to be clarified (for details see Table 1).

Description. Average-sized Thecidellina, shell whitish, ventral valve cemented to substrate, position and size of resulting cicatrix variable. Ventral valve with flat triangular interarea (Fig. 2a, b). Straight hinge line without notch (Fig. 2a, b); teeth sturdy, triangular (Fig. 3c); hemispondylium with calcitic plate lifted from floor of ventral valve cavity (Fig. 2b); calcitic plate ventrally connecting two diverging and dorsally pointing curved prongs; ventral valve without median ridge, but rather deep ventral cavity with irregularly distributed small tubercles capped with secondary shell fibres. Overall appearance of ventral valve floor smooth (Fig. 2a).

Dorsal valve with rather broad median septum and trilobed cardinal process; outer lateral parts of cardinal process (=inner socket ridges) and tubercles with secondary shell fibres, rest of dorsal valve only primary layer shell material. Interbrachial lobes in all investigated specimens without canopying spicules, but with intrabrachial ridge constructed by calcitic lamellae, giving the interbrachial lobes a regularly striped appearance (Fig. 2c). Caudal end of median septum forming a roundish calcitic opening for the mouth part of the soft body (Figs 2c, 3a). On either side of this opening are slit-like holes, allowing parts of the mantle supposed to support the nephridiopores to contact the outer medium. Brachial bridge supported by triangular calcitic pole with irregular caudal outgrowths (Fig. 3b) of small papillae to larger prongs.

Thecidellina bahamiensis Lüter \& Logan, sp. nov. Figures $2 \mathrm{~d}-\mathrm{f}, 3 \mathrm{~d}-\mathrm{f}, \mathrm{k}, 1$

-as Thecidellina cf. T. barretti: Cooper, 1977, p. 132, pl. 3, figs. 19-21

Type specimens. ZMB Bra 2075, holotype (1, valves separated), dry, SEM-preparation. ZMB Bra 2076, paratypes (3, valves separated), dry. ZMB Bra 2080, paratypes (6 dv, $1 \mathrm{vv}$ ), dry, partly SEM-preparation.

Type locality. Green Cay, Tongue of Ocean, Bahamas, collected from Nekton submersible by R. Assereto on 11 January 1976 at a depth of $110 \mathrm{~m}$.
Additional material. Topotypic material is available from South West Reef, Tongue of Ocean, collected by N. P. James in January 1976 with the NEKTON submersible at a depth of $71 \mathrm{~m}$. Further topotypes from Freeport Cave, Grand Bahama Island, Bahamas, at a depth of $20 \mathrm{~m}$, collected by J. Vacelet, date unknown. Material from Goat Cay, off Small Hope Bay (Cooper, 1977) has also been identified as T. bahamiensis (for details see Table 1).

Etymology. This species is named after the collecting site, the Bahamas.

Description. Average-sized Thecidellina, shell whitish, roughly triangular ventral valve cemented to substrate, position and size of resulting cicatrix variable. Ventral valve with flat triangular interarea (Fig. 2e) and frontal sulcus in some specimens. Straight hinge line without notch; triangular teeth pointed dorsally (Fig. 3f); hemispondylium with two diverging and dorsally pointing curved prongs; without connecting ventral plate, prongs ventrally connected to median ridge (Fig. 2d, e). Median ridge irregularly fissured (Fig. 2d, e). Floor of ventral valve tuberculate and partly covered with raised calcitic papillae, especially on median ridge; deep gonad pits on either side of median ridge (Fig. 2d).

Dorsal valve with narrow, spine-like median septum and trilobed cardinal process (Fig. 2f). Outer lateral parts of cardinal process, ventral teeth, inner socket ridges and tubercles with secondary shell fibres, rest of dorsal valve only primary layer shell material. Interbrachial lobes with single canopying spicules (Fig. 2f). Caudal end of median septum forming ill-defined roundish opening for the mouth (Figs $2 \mathrm{f}$, $3 \mathrm{~d}$ ); on either side of this opening very small holes, allowing parts of the mantle assumingly supporting the nephridiopores to contact the outer medium, holes partly covered with papillose calcitic facings (Fig. 3d). Brachial bridge supported by triangular calcitic pole with irregular caudal outgrowths of small papillae to larger prongs (Fig. 3e).

Notes. Cooper (1977) mentioned two Caribbean collecting sites where Thecidellina was found: (1) Pillsbury station P 630, off Trujillo, Honduras; and (2) El Torito station NGS-MRF33, Goat Cay, Bahamas (for details of collecting sites: see Cooper 1977, p. 20 and p. 35). Because of the strong tuberculation of the ventral valve in his specimens from Honduras, he identified them as 'Thecidellina cf. T. barretti', certainly knowing that such a strongly tuberculate ventral valve is unusual for the species. According to the present study, the Thecidellina specimens from the Bahamas belong to a new species, $T$. bahamiensis, a diagnostic character of which is an identical tuberculation in the ventral valve, absent in all other Caribbean Thecidellina specimens examined so far. Since Cooper had also a Bahamian specimen with a smooth internal surface of the ventral valve, which he identified as $T$. barretti, there is a strong suspicion, that Cooper mislabelled the specimens. His Thecidellina $\mathrm{cf}$. T. barretti (pl. 3, figs. 19-21) almost certainly comes from the Bahamas and belongs to the new species $T$. bahamiensis, whereas his T. barretti (pl. 3, figs. 22-26) surely is the specimen from Honduras (see also Table 1).

Thecidellina williamsi Lüter \& Logan, sp. nov. Figures $2 \mathrm{~g}-\mathrm{i}, 3 \mathrm{~g}-\mathrm{i}, \mathrm{m}$

-as Thecidellina barretti: Logan, 1988, p. 69; 1993, p. 230

Type specimens. ZMB Bra 2073, holotype (1, valves separated), dry, SEM-preparation. ZMB Bra 2074, paratypes $(2,6 \mathrm{dv})$, dry, partly SEM-preparation. Private collection A. Logan, paratypes (18), dry. 

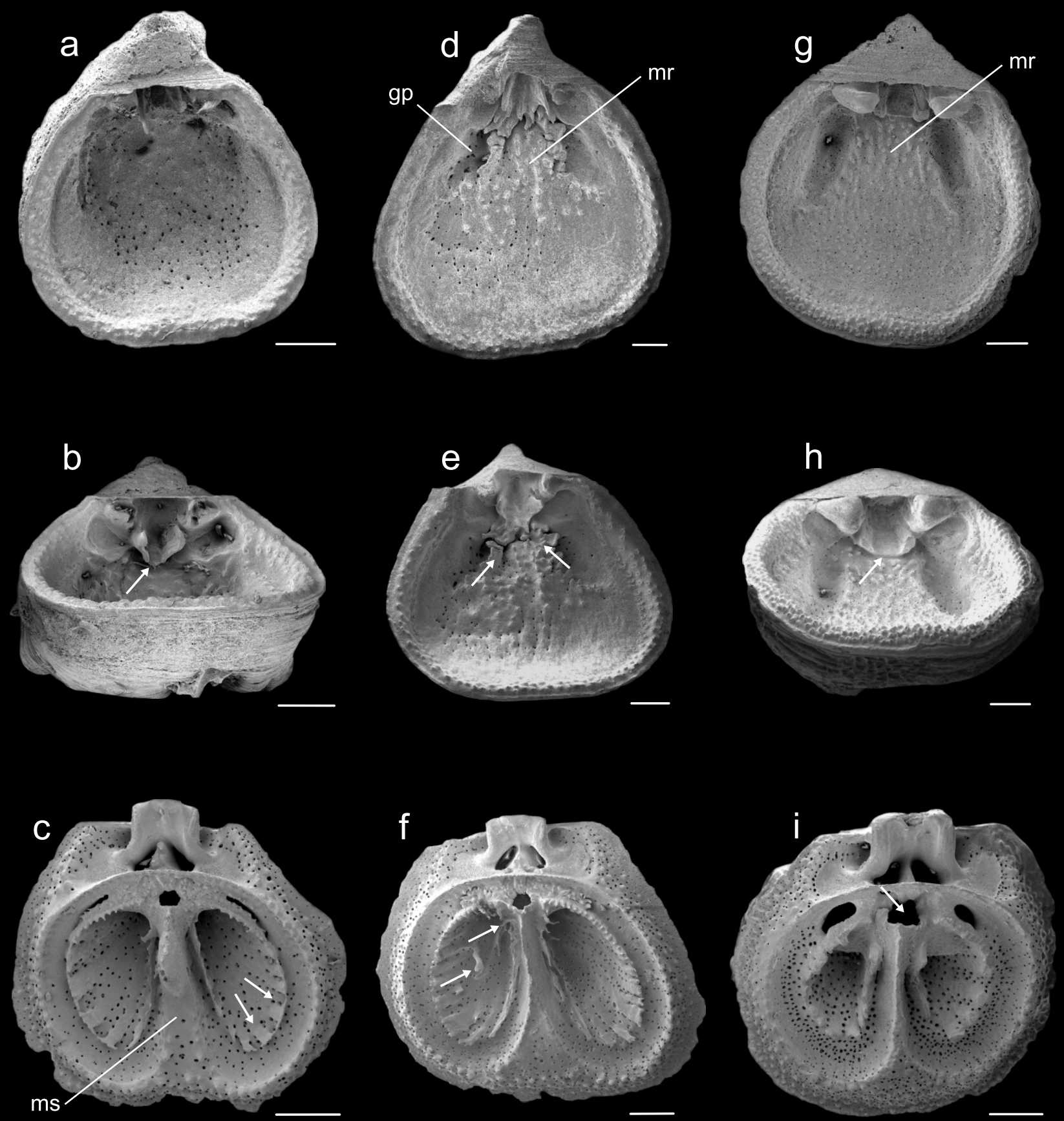

Figure 2 (a-c) Thecidellina barretti, ZMB Bra 2077: (a) Specimen 'a', ventral valve with smooth internal floor, dorsal view; (b) same as (a), frontal view. Notice the uplifted horizontal plate of the hemispondylium (arrowed); (c) Specimen ' $b$ ', dorsal valve with striped appearance of the intrabrachial ridge (arrowed) and median septum (ms). (d-f) Thecidellina bahamiensis sp. nov., ZMB Bra 2075, holotype: (d) Ventral valve with median ridge (mr), strongly spiculated internal floor and deep gonad pits (gp); (e) same as (d), frontal view. Notice the strong spiculation (arrowed) of the valve floor. Prongs of the hemispondylium are directly connected to the valve floor; (f) Dorsal valve with single canopying spicules (arrowed). (g-i) Thecidellina williamsi sp. nov., ZMB Bra 2073, holotype: (g) Ventral valve. Notice the median ridge (mr), deep gonad pits and sturdy teeth; (h) same as g, frontal view. The hemispondylium has a horizontal plate (arrowed), which is connected to the median ridge; (i) Dorsal valve. Notice the rather small intrabrachidial lobes and the large holes on either side of the rectangular caudal opening for the mouth (arrowed) of the animal. All scale bars $=500 \mu \mathrm{m}$. 

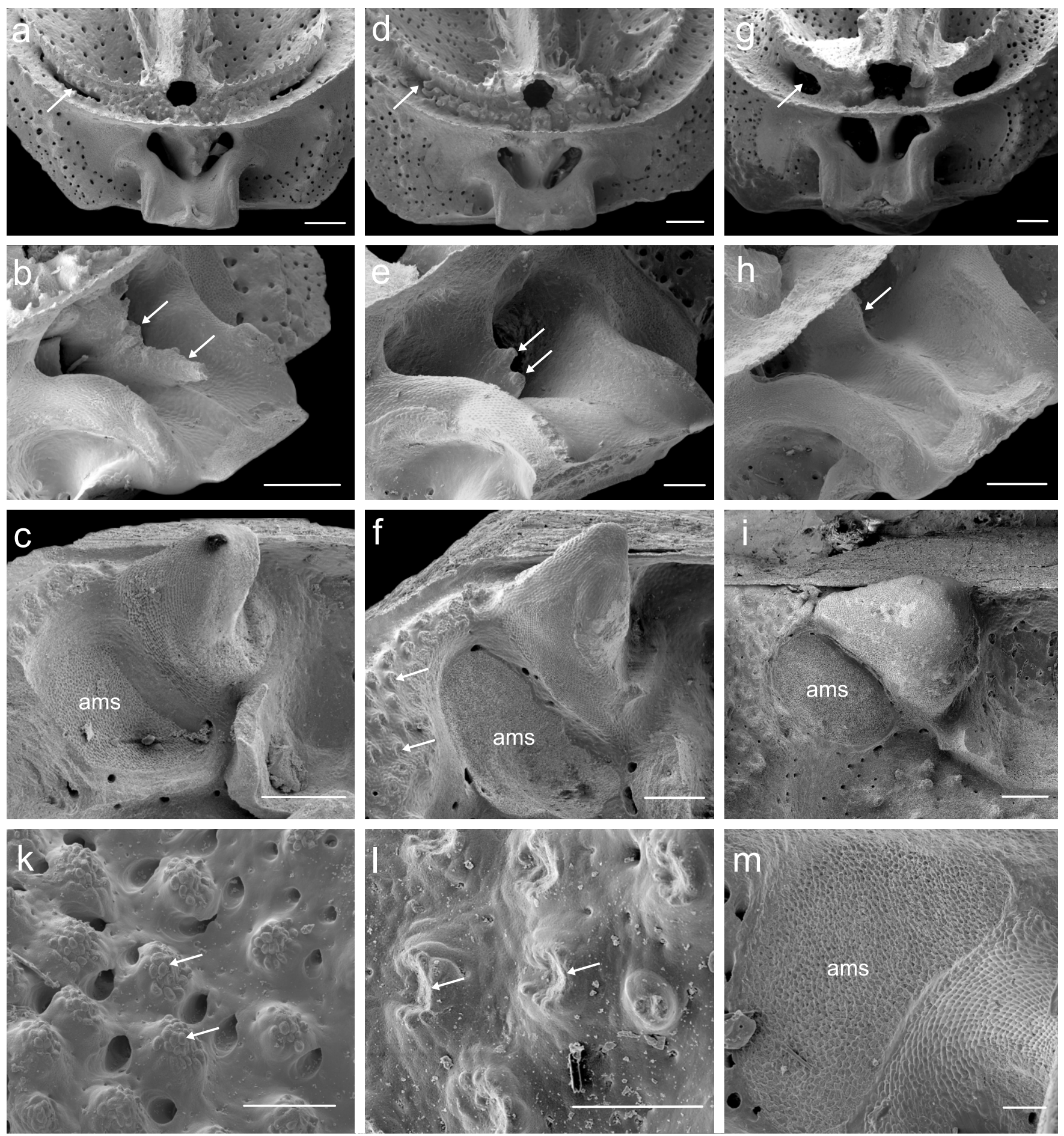

Figure 3 (a-c) Thecidellina barretti, ZMB Bra 2077: (a) Specimen 'b', dorsal valve, caudal view. The assumed nephridiopore-bearing holes between peri- and intrabrachial ridge form curved slits (arrowed); (b) Specimen 'a', dorsal valve, bridge-supporting pole with irregular calcitic outgrowths (arrowed); (c) Specimen 'b', ventral valve, right tooth with secondary shell fibres and adductor muscle scar (ams). (d-f) Thecidellina bahamiensis sp. nov.: (d) ZMB Bra 2075, holotype. Dorsal valve, caudal view. Nephridiopore-bearing holes (arrowed) pinpointed by covering calcitic spicules; (e) ZMB Bra 2080, paratype 'a'. Dorsal valve, bridge-supporting pole with irregular calcitic outgrowths (arrowed); (f) ZMB Bra 2080, paratype ' $b$ '. Triangular right tooth and adductor muscle scar (ams) in the ventral valve. Notice the concave tubercle tips at the rim of the valve (arrowed). ( $\mathrm{g}-\mathrm{i})$ Thecidellina williamsi sp. nov.: (g) ZMB Bra 2073, holotype. Dorsal valve, caudal view. Large kidney-shaped nephridioporebearing holes (arrowed) on either side of the rectangular caudal opening of the median septum; (h) ZMB Bra 2074, paratype 'a'. Dorsal valve, bridge-supporting smooth pole without any outgrowths (arrowed); (i) ZMB Bra 2073, holotype, ventral valve. Blunt right tooth and roundish adductor muscle scar (ams). (k-1) Thecidellina bahamiensis sp. nov., ZMB Bra 2080, paratypes: (k) paratype 'a', tubercles of dorsal valve near cardinal process topped with secondary shell fibres (arrowed); (1) paratype ' $b$ ', ventral valve. Concave tubercles at the rim of the valve with secondary shell fibres (arrowed). (m) Thecidellina williamsi sp. nov., ZMB Bra 2074, paratype 'b'. Dorsal valve, caudal view. Kidney-shaped right adductor muscle scar (ams). Notice secondary shell fibres on socket ridge and rim of cardinal process. Scale bars: $a-d, f-i=200 \mu \mathrm{m} ; \mathrm{e}, \mathrm{k}, \mathrm{l}=100 \mu \mathrm{m} ; \mathrm{m}=50 \mu \mathrm{m}$. 
Type locality. São Tiago, Tarrafal, Cape Verde, Atlantic; in a cave at $12 \mathrm{~m}$ depth, collected by P. Wirtz, December 1998.

Additional material. Topotypes from CANCAP VI 'Tydeman' expedition 1982 to Cape Verde: three stations from the vicinity of São Tiago and São Nicolau (van der Land 1987; Logan 1988, 1993).

Etymology. The species is named after the late Sir Alwyn Williams, who dedicated his scientific life to brachiopod evolutionary research, and who gave the first comprehensive account of the ultrastructure of thecideide shell morphology (Williams 1973).

Description. Average-sized Thecidellina, shell whitish, roundish ventral valve cemented to substrate, position and size of resulting cicatrix variable. Ventral valve with flat triangular interarea (Fig. $2 \mathrm{~g}, \mathrm{~h}$ ). Straight hinge line without notch; teeth rather blunt and massive, triangular (Fig. 3i); hemispondylium with calcitic plate ventrally connecting two diverging and dorsally pointing curved prongs; calcitic plate ventrally cemented on a massive median ridge (Fig. 2h) broadening towards the shell's frontal margin. Deep gonad pits on either side of the ridge carrying parts of the coelomic cavity with gonads (Fig. 2g, h). Floor of ventral valve tuberculate.

Dorsal valve with narrow, spine-like median septum and trilobed cardinal process; outer lateral parts of cardinal process, inner socket ridges, ventral teeth, and tubercles with secondary shell fibres, rest of dorsal valve only primary layer shell material. Interbrachial lobes sometimes with single canopying spicules. Caudal end of median septum forming ill-defined rectangular opening for the mouth (Figs 2i, 3g). On either side of this opening kidney-shaped large holes (Figs 2i, $3 \mathrm{~g}$ ) which are assumed to enable nephridial pores to contact the surrounding water. Brachial bridge with supporting pole; pole without caudally protruding spines or prongs, pole surface smooth (Fig. 3h).

\section{Discussion}

Thecidellina barretti (Davidson, 1864) is known from the Caribbean since the Upper Pliocene according to Davidson's original description. The type specimens were collected by Lucas Barrett on the north coast of Jamaica. Subsequent sampling of this species for scientific investigations was done near the type locality, e.g. at Rio Bueno (B.L. Cohen, pers. comm. 2000), at Discovery Bay (Williams 1973) and at Runaway Bay (Jackson et al. 1971). Additionally, specimens found at other localities in the Caribbean were identified as $T$. barretti or $T$. cf. barretti mainly because of overall similarity of the shells or simply because of their Caribbean origin (see Jackson et al. 1971; Cooper 1977; Logan 1981, 1988, 1990, 1993, 2007). Even shells from the Bahamas (Cooper 1977) and from Cape Verde (Logan 1988, 1993), the latter lying some $5500 \mathrm{~km}$ east of Jamaica, were identified as T. barretti, i.e. all Thecidellina specimens with Atlantic/Caribbean affiliation collected so far were lumped into a single species. This is understandable, because of the macroscopic similarity between all these specimens. The rarity of obvious diagnostic and discriminating characters within the genus led to the small number of only six valid species descriptions within Thecidellina despite its worldwide distribution (Pajaud 1970; Lee \& Robinson 2003). The problem of identifying Thecidellina species beyond doubt also hampered early attempts to resolve their phylogenetic position within the phylum using molecular methods (Cohen \& Gawthrop 1997; Cohen et al. 1998), since sequence data were attributed to misidentified shells. Cohen worked with specimens collected at Guam/Pacific which were erroneously identified as $T$. blochmanni, the type locality of which is Christmas Island/Indian Ocean, several thousand kilometres southwest of Guam. Whenever Thecidellina specimens were found in the past, they were either often left undescribed and accordingly listed as Thecidellina sp. or artificially pressed into one of the six available species, either depending on geographical provenance or macroscopic resemblance to already described species.

Investigation by the present authors shows that a different set of characters is needed to discriminate between thecideide species, and that species-specific morphological differences show up when the scanning electron microscope is used to examine the shells. Useful morphological characters, at least for Atlantic/Caribbean species discrimination are: (1) the shape and ventral basis of the hemispondylium; (2) spiculation; (3) occurrence and shape of a median ridge in the ventral valve; (4) the morphology of the calcitic pole supporting the brachial bridge; and (5) shape and size of two holes in the intrabrachial ridge supposed to provide an opening for the nephridiopores (see Table 2). However, caution is needed here as well, since intraspecific variability is widespread in Thecidellina, i.e. a critical number of specimens is needed to minimize variability effects. Lee \& Robinson (2003) discussed the insufficient quality of morphological characters used in the past to distinguish between Thecidellina species. However, in the case of the ' $T$. barretti-complex', constant morphological differences between specimens from Jamaica, Bahamas and Cape Verde justified the description of two new species, T. bahamiensis Lüter \& Logan from the Bahamas and T. williamsi Lüter \& Logan from Cape Verde, thereby increasing the known diversity of Atlantic Thecidellina. The affiliation of Thecidellina from other localities in the Caribbean, like Cayman Islands (Logan 1977, 1981), Curaçao (Jackson et al. 1971) or Honduras (Cooper 1977) remains to be tested by re-investigation of their shell ultrastructure and (even more important and in accordance with the suggestion of Lee \& Robinson (2003)) by molecular methods using genetic markers with high resolution, since a relatively recent radiation of Thecidellina in the Caribbean region is likely to be responsible for the distributional pattern found today.

This hypothesis would also be in accordance with Caribbean plate tectonics (see Hedges 1982 and references therein). Many reefs where Caribbean Thecidellina specimens were found sit on top of the Caribbean tectonic plate, including the type locality of $T$. barretti at the central north coast of Jamaica. The Caribbean plate is separated from the North American plate by deep trenches, the Cayman Trough in the west and the Puerto Rico Trough in the east. With the Cayman Trough being over $7 \mathrm{~km}$ deep, it is possible that the ambient current systems inhibit a direct exchange of propagules across this deep trench. This is supported by high-resolution biophysical models applied to Caribbean reef fish populations (Cowen et al. 2006). Typical larval dispersal distances in many Caribbean reef fish are less than $100 \mathrm{~km}$ with (1) a clear dispersal barrier parallel to the Cayman Trough and (2) a significant isolation of the Bahamas from the remaining Caribbean region (Cowen et al. 2006). In accordance with Cowen et al. (2006), the relative isolation of the two Caribbean locations in the present investigation, i.e. Jamaica and the Bahamas, is likely to provide the necessary distance for allopatric speciation reflected in the occurrence of distinct Thecidellina species in the two regions.

Earlier simulations of larval dispersal (Cowen et al. 2000, 2003) showed that eastbound travelling larvae roughly reached $56^{\circ}$ East during 30 days starting from Barbados. This calculated travelling distance is only about a third of what Thecidellina larvae would need to reach Cape Verde from 
Table 2 Tabulation of diagnostic differences between the three species, based mainly on internal skeletal characteristics

\begin{tabular}{|c|c|c|}
\hline $\begin{array}{c}\text { Thecidellina barretti s.s. } \\
\text { JAMAICA }\end{array}$ & $\begin{array}{c}\text { Thecidellina bahamiensis } \\
\text { BAHAMAS }\end{array}$ & $\begin{array}{l}\text { Thecidellina williamsi } \\
\text { CAPE VERDE }\end{array}$ \\
\hline Ventral valve with slight frontal sulcus & $\begin{array}{l}\text { Ventral valve with frontal sulcus in some } \\
\text { specimens }\end{array}$ & Ventral valve with no frontal sulcus \\
\hline $\begin{array}{l}\text { Ventral valve interior with hemispondylium } \\
\text { lifted from floor of ventral valve cavity, } \\
\text { unsupported by median ridge }\end{array}$ & $\begin{array}{l}\text { Ventral valve interior with hemispondylium } \\
\text { base supported by median ridge, connecting } \\
\text { plate and gonadal pits often obscured by } \\
\text { spiculate sub-floor }\end{array}$ & $\begin{array}{l}\text { Ventral valve interior with hemispondylium } \\
\text { attached to and supported by massive } \\
\text { tuberculate median ridge broadening } \\
\text { anteriorly and flanked by deep gonadal pits }\end{array}$ \\
\hline $\begin{array}{l}\text { Ventral valve interior smooth or sparsely } \\
\text { tuberculate }\end{array}$ & $\begin{array}{l}\text { Ventral valve interior heavily spiculate, } \\
\text { forming almost continuous sub- floor in many } \\
\text { specimens; strongly tuberculate }\end{array}$ & $\begin{array}{l}\text { Ventral valve interior smooth or sparsely } \\
\text { tuberculate }\end{array}$ \\
\hline $\begin{array}{l}\text { Dorsal valve interior with roundish opening at } \\
\text { caudal end of median septum, flanked by pair } \\
\text { of nephridiopore slits }\end{array}$ & $\begin{array}{l}\text { Dorsal valve interior with roundish opening at } \\
\text { caudal end of median septum, flanked by pair } \\
\text { of almost invisible nephridiopore openings }\end{array}$ & $\begin{array}{l}\text { Dorsal valve interior with prominent } \\
\text { rectangular opening at caudal end of median } \\
\text { septum, flanked by pair of kidney-shaped } \\
\text { nephridiopore openings }\end{array}$ \\
\hline $\begin{array}{l}\text { Dorsal valve interior with central median } \\
\text { septum, wide anteriorly, tapering slightly } \\
\text { posteriorly }\end{array}$ & $\begin{array}{l}\text { Dorsal valve interior with narrow, almost } \\
\text { parallel-sided median septum, tapering to a } \\
\text { sharp point posteriorly }\end{array}$ & $\begin{array}{l}\text { Dorsal valve interior with narrow median } \\
\text { septum, tapering to a blunt end posteriorly }\end{array}$ \\
\hline $\begin{array}{l}\text { Dorsal valve interior with brachidial bridge } \\
\text { supported by triangular calcitic pole with } \\
\text { irregular outgrowths }\end{array}$ & $\begin{array}{l}\text { Dorsal valve interior with brachidial bridge } \\
\text { supported by triangular calcitic pole with } \\
\text { irregular outgrowths }\end{array}$ & $\begin{array}{l}\text { Dorsal valve interior with brachidial bridge } \\
\text { supported by smooth, narrow parallel-sided } \\
\text { pole with no outgrowths }\end{array}$ \\
\hline
\end{tabular}

Jamaica or vice versa. Additionally, Thecidellina larvae are passive drifters rather than active swimmers, with an assumed survival rate significantly shorter than 30 days. Provided that the model can be transferred to reef dwelling sessile filterfeeding brachiopods and their lecithotrophic larvae, gene flow between Cape Verdean and Jamaican populations of Thecidellina is, therefore, highly unlikely.

In summary, Thecidellina barretti, as previously recognised throughout Caribbean and Atlantic localities, must be regarded as a complex of at least three cryptic species, which clearly differ in their shell ultrastructure (Table 2). Although independent modelling of larval dispersal of Caribbean reef fishes (Cowen et al. 2006) corroborates this hypothesis, further confirmation from molecular studies already in preparation is urgently needed.

\section{Acknowledgements}

Thanks are due to Gordon B. Curry (Glasgow, UK), who collected the specimens from Jamaica, and Peter Wirtz (Madeira, Portugal), who collected most of the specimens from Cape Verde investigated in this study. Specimens were partly made available by Bernard L. Cohen (Glasgow, UK) from his voucher collection. AL thanks Judith Lang (Austin, Texas) for sending NEKTON material from the Bahamas. We also thank Gabriele Drescher for technical assistance at the electron microscopy lab of the Museum für Naturkunde, Berlin and staff of the Microscopy and Microanalysis unit at the University of New Brunswick, Fredericton. Financial support by the European Commission's Research Infrastructure Action via the SYNTHESYS Project (GB TAF 267 to CL) and by the Deutsche Forschungsgemeinschaft (LU 839/3-1) is gratefully acknowledged.

\section{References}

Cohen, B. L., Gawthrop, A. B. \& Cavalier-Smith, T. 1998. Molecular phylogeny of brachiopods and phoronids on nuclear-encoded small subunit ribosomal RNA gene sequences. Philosophical Transactions of the Royal Society, London B 353, 2039-61.

Cohen, B. L. \& Gawthrop, A. B. 1997. The brachiopod genome. In Kaesler, R. L. (ed.) Treatise on Invertebrate Paleontology, part H: Brachiopoda, Revised, Vol. 1, 189-211. Boulder, Colorado and Lawrence, Kansas: Geological Society of America and University of Kansas Press.

Cooper, G. A. 1977. Brachiopods from the Caribbean Sea and adjacent waters. Studies in Tropical Oceanography 14, 1-221.

Cowen, R. K., Lwiza, K. M. M., Sponaugle, S., Paris, C. B. \& Olson, D. B. 2000. Connectivity of marine populations: open or closed? Science 287, 857-9.

Cowen, R. K., Paris, C. B., Olson, D. B. \& Fortuna, J. L. 2003. The role of long distance dispersal versus local retention in replenishing marine populations. Gulf and Caribbean Research 14, 129-38.

Cowen, R. K., Paris, C. B. \& Srinavasan, A. 2006. Scaling of connectivity in marine populations. Science 311, 522-7.

Davidson, T. 1864. On the Recent and Tertiary species of the genus Thecidium. The Geological Magazine 1, 12-22.

Hedges, S. B. 1982. Caribbean biogeography: implications of recent plate tectonic studies. Systematic Zoology 31, 518-22.

Jackson, J. B. C., Goreau, T. F. \& Hartmann W. D. 1971. Recent brachiopod-coralline sponge communities and their paleoecological significance. Science 173, 623-5.

James, M. A., Ansell, A. D., Collins, M. J., Curry, G. B., Peck, L. S. \& Rhodes, M. C. 1992. Biology of living brachiopods. Advances in Marine Biology 28, 175-387.

Lacaze-Duthiers, H. 1861. Histoire naturelles des brachiopodes vivantes de la Méditerranée. Annales des Sciences Naturelles, série 4 15, 260-330.

Lee, D. E. \& Robinson, J. E. 2003. Kakanuiella (gen. nov.) and Thecidellina: Cenozoic and Recent thecideide brachiopods from New Zealand. Journal of the Royal Society of New Zealand 33, $341-61$. 
Logan, A. 1977. Reef-dwelling articulate brachiopods from Grand Cayman, BWI. Proceedings of the Third International Coral Reef Symposium 1, 87-93.

Logan, A. 1981. Sessile invertebrate coelobite communities from shallow reef tunnels, Grand Cayman, BWI. Proceedings of the Fourth International Coral Reef Symposium 2, 735-44.

Logan, A. 1988. Brachiopoda collected by CANCAP IV and VI expeditions to the south-east north Atlantic, 1980-1982. Zoologische Mededelingen, Leiden 62, 59-74.

Logan, A. 1990. Recent Brachiopods from the SNELLIUS and LUYMES expeditions to the Surinam-Guyana shelf, BonaireCuraçao, and Saba Bank, Caribbean Sea, 1966 and 1969-1972. Zoologische Mededelingen, Leiden 63, 123-36.

Logan, A. 1993. Recent Brachiopods from the Canarian-Cape Verdean region: diversity, biogeographic affinities, bathymetric range and life habits. Courier des Forschungsinstituts Senckenberg 159, 229-33.

Logan, A. 2004. Ecological, reproductive and ontogenetic features in Pajaudina atlantica Logan (Thecideidae, Brachiopoda, Recent) from the Canary Islands. P.S.Z.N.: Marine Ecology 25, 207-15.

Logan, A. 2005. A new lacazelline species (Brachiopoda, Recent) from the Maldive Islands, Indian Ocean. Systematics and Biodiversity $\mathbf{3}$, 97-104.

Logan, A. 2007. Geographic distribution of extant articulated brachiopods. In Selden, P. E. (ed.) Treatise on Invertebrate Paleontology, part H: Brachiopoda, Revised, Vol. 6, 3082-115. Boulder, Colorado and Lawrence, Kansas: Geological Society of America and University of Kansas Press.

Lüter, C. 2005. The first Recent species of the unusual brachiopod Kakanuiella (Thecideidae) from New Zealand deep waters. Systematics and Biodiversity 3, 105-11.
Lüter, C. 2007. Anatomy. In Selden, P. E. (ed.) Treatise on Invertebrate Paleontology, part H: Brachiopoda, Revised, Vol. 6, 2321-55. Boulder, Colorado and Lawrence, Kansas: Geological Society of America and University of Kansas Press.

Meidlinger, K., Tyler, P. A. \& Peck, L. S. 1998. Reproductive patterns in the Antarctic brachiopod Liothyrella uva. Marine Biology 132, $153-62$.

Pajaud, D. 1970. Monographie des Thécidées (Brachiopodes). Mémoires de la Société géologique de France (Nouvelle série) 112, $1-345$.

Peck, L. S., Meidlinger, K. \& Tyler, P. A. 2001. Development and settlement characteristics of the Antarctic brachiopod Liothyrella uva (Broderip, 1833). In Brunton, C. H. C., Cocks, L. R. M. \& Long, S. L. (eds) Brachiopods - Past and Present, 80-90. London: Taylor and Francis.

Richardson, J. R. 1997. Ecology of articulate brachiopods. In Kaesler, R. L. (ed.) Treatise on Invertebrate Paleontology, part H: Brachiopoda, Revised, Vol. 1, 441-62. Boulder, Colorado and Lawrence, Kansas: Geological Society of America and University of Kansas Press.

Thomson, J. A. 1915. On a new genus and species of the Thecidiinae (Brachiopoda). The Geological Magazine, Dec. 6, new series 2, 461-4.

van der Land, J. 1987. Report on the CANCAP-project for marine biological research in the Canarian-Cape Verdean region of the North Atlantic Ocean (1976-1986). Part 1. List of stations. Zoologische Verhandelingen, Leiden 243, 1-94.

Williams, A. 1973. The secretion and structural evolution of the shell of thecideidine brachiopods, Philosophical Transactions of the Royal Society London, B 264, 439-78. 